\title{
Carcass and Meat Characteristics of Bulls from Arsi, Boran, Harar and Holstein Frisian Crosses Cattle Breeds Finished under Similar Level of Concentrate Supplementation
}

\author{
Ahmedin Abdurehman Musa1*, Yesihak Yusuf Mummed ${ }^{2}$, Mohammed Yusuf Kurtu2, \\ Melese Temesgen ${ }^{3}$, Travis Gene 0'Quinn ${ }^{4}$ \\ ${ }^{1}$ Department of Animal Science, College of Agriculture, Oda Bultum University, Chiro, Ethiopia \\ ${ }^{2}$ School of Animal and Range Sciences, College of Agriculture and Environmental Sciences, Haramaya University, \\ Dire Dawa, Ethiopia \\ ${ }^{3}$ Department of Food Science, Institute of technology, Haramaya University, Dire Dawa, Ethiopia \\ ${ }^{4}$ Department of Animal Sciences and Industry, Kansas State University, Manhattan, USA \\ Email: *ahmedin133@gmail.com
}

How to cite this paper: Musa, A.A., Mummed, Y.Y., Kurtu, M.Y., Temesgen, M. and O'Quinn T.G. (2021) Carcass and Meat Characteristics of Bulls from Arsi, Boran, Harar and Holstein Frisian Crosses Cattle Breeds Finished under Similar Level of Concentrate Supplementation. Open Journal of Animal Sciences, 11, 11-30. https://doi.org/10.4236/ojas.2021.111002

Received: October 6, 2020

Accepted: January 24, 2021

Published: January 27, 2021

Copyright $\odot 2021$ by author(s) and Scientific Research Publishing Inc. This work is licensed under the Creative Commons Attribution International License (CC BY 4.0).

http://creativecommons.org/licenses/by/4.0/ (c) (i) Open Access

\begin{abstract}
A study was conducted to evaluate the effect of age and breeds (Arsi, Borana, HF-Cross and Harar) on carcass and meat characteristics of bulls finished under similar feeding conditions. The feeding experiment was conducted for 90 days at Beef farm of Haramaya University. In this experiment, 24 bulls were fed with roughage $(60 \%)$ which contained grass hay and wheat straw and concentrate (40\%) which contained wheat bran, noug (gucia abysica) cake, maize grain, limestone, salt and ruminant premix. The bulls were transported to Bishoftu ELFORA export abattoir for slaughter following the procedure of the abattoir. The result of the study revealed that the average slaughter weight, hot carcass weight, cold carcass weight, shrink loss, commercial dressing and true dressing percentage were $179.1 \mathrm{~kg}, 86.8 \mathrm{~kg}, 82.7 \mathrm{~kg}$ $4.7 \%, 48.8 \%$ and $78.3 \%$, respectively. Total edible and nonedible offal were significantly $(\mathrm{P}<0.01)$ influenced by breed and age. Pelvic fat was significantly $(\mathrm{P}<0.01)$ influenced by breeds. Meat yield percentages of Arsi, Boran, Harar, and HF-crossbred were $78.1 \%, 77 \%, 72.8 \%$ and $77.2 \%$ respectively. Meat yield was predicted from fat thickness and ribeye area with $61 \%$ accuracy. Arsi bulls attained the highest (78\%) meat yield at early age but decreased by 0.713 rate as age of animals advanced by one digit whereas the meat yield from other breeds showed increment in meat yield percentage with the rate of 1.98, 1.1 and 0.1 for cross, Borana and Harar breed bulls, respectively as age advanced. Yield from fore shank, sirloin, top and bottom sirloin primal cuts
\end{abstract}


were affected by breed. Arsi breed had higher meat bone ration than cross breed. Retailed meat yield was significantly $(\mathrm{P}<0.001)$ predicted from rib area and subcutaneous fat thickness $(\mathrm{P}<0.001)$ with a coefficient of determination $61 \%$, from live animal trait and primal cuts with a coefficient of determination $89.56 \%$ and $94.78 \%$ respectively. Arsi bulls can be used for beef purpose at 2 - 3 years, as the meat percentage decreases thereafter; while bulls from Boran, cross breed and Harar breeds can be used up to 5 years of age. Meat to bone ratio indicated that HF-Crossbred was less appropriate for beef purpose than other breed bulls in this study. The rate of $\mathrm{pH}$ decline was not influence $(\mathrm{P}>0.05)$ by age and breed in the current study.

\section{Keywords}

Carcass pH, Meat Characteristics, Carcass Yield

\section{Introduction}

Ethiopia is one of the lowest per capita meat consuming countries ( $9 \mathrm{~kg} / \mathrm{capita} /$ year) compared to consumptions of red meat in Africa [1]. The contribution of beef to the per capita consumption accounted for $4.3 \mathrm{~kg} /$ capita/year [2]. The average carcass yield/cattle in Ethiopia was estimated to be $135.90 \mathrm{~kg}$ [3] which was below the average carcass yield in developing countries [2]. Clear evidence of the very low productive performance of the livestock sector is due to low genetic potential of indigenous animals and poor livestock husbandry systems [4] [5]. Ethiopia needs to improve the meat sector to achieve its goal of becoming a middle-income country by 2025 . It is projected that the population of Ethiopia will grow by $25 \%$ between 2012 and 2025, reaching 120 million people by 2030 [6]. The increase in population and the available export market in the Middle East indicate a significant increase in demand for meat and meat products production in Ethiopia [7] [8]. Beef is one of the most widely consumed animal protein sources in human nutrition in Ethiopia and worldwide. To satisfy the meat demand at local and export markets, the country needs to characterize and document the potential of cattle breeds in respect to meat and carcass yield and quality. However, little information is available so far on yields, meat cut and quality characteristics of indigenous cattle breeds in Ethiopia [9] [10].

Some studies were conducted in different corners of the country at different experimental stations like: on Harar bulls [11], Borana, Arsi, and Harar bulls [12], Boran, Kereyu and Ogaden [13] [14] cattle carcass characteristics. However, little information is available on carcass characteristics, meat yield, yield percentage and meat cut of Ethiopian cattle finished under similar preslaughter management. A study by [12] suggested the possibilities of age and breeds of cattle in significantly influencing carcass and meat characteristics bulls from Arsi, Boran, Harar cattle breeds. However, the result was not conclusive as the meat and carcass characteristics of these breeds were evaluated being purchased 
directly from their respective production systems. The researchers have suggested the need to determine whether variations are due to genetic or environmental. Hence, evaluation of the three breeds under similar feeding was recommended. Therefore, this study was conducted to evaluate the effect of age and breeds on carcass and meat characteristics of bulls from Arsi, Borana, HF-Cross and Harar breed finished under similar concentrate supplementation.

\section{Materials and methods}

\subsection{Description of the Study Area}

Evaluation of carcass and meat characteristics of cattle breeds were conducted based on slaughter of the bulls at Elfora Beshoftu Abattoir. The abattoir is located $62 \mathrm{~km}$ east of Addis Ababa. The experimental animal feeding was conducted at Haramaya University beef fattening unit. It is located at $9.0^{\circ} \mathrm{N}$ latitude and $42.0^{\circ} \mathrm{E}$ longitude at an altitude of $1980 \mathrm{~m}$ above sea level and $515 \mathrm{~km}$ east of Addis Ababa, Ethiopia. The area receives annual average rainfall of $790 \mathrm{~mm}$ and annual mean temperature of $16^{\circ} \mathrm{C}$.

\subsection{Animal Management}

The experimental animals consist of total of 24 intact bulls were grouped into two age groups ( 2 - 3 years and 4 - 5 years) of four breeds (Borana, Arsi, Hararghe and Holstein Frisian cross with local breed) of which 6 intact bulls per breeds and 3 intact bulls per age group were used in this study. They were stayed for 90 days being supplied with roughage (60\%) and concentrate (40\%). The roughage consisted of natural grass hay (55\% of roughage) and wheat straw ( $45 \%$ of roughage) and the concentrate consisted of $34.78 \%$ wheat bran, $27.8 \%$ Noug (gucia abysica) cake, $33.14 \%$ maize grain, $1.7 \%$ limestone and $1.7 \%$ salt and $0.88 \%$ ruminant premix.

\subsection{Experimental Design}

A factorial arrangement with two factors (breed and age) and three replications in the CRD (Completely Randomized Design) was used to evaluate carcass yield, quality and meat characteristics as shown in the arrangement was indicated in Table 1.

\subsection{Slaughter Procedure and Evaluation of Carcass and Meat Characteristics}

At the end of 90 days experimental feeding, all bulls were loaded on appropriate

Table 1. Treatment arrangement to evaluate carcass yield, quality and meat characteristics.

\begin{tabular}{|c|c|c|c|c|c|}
\hline \multirow{2}{*}{ Age } & \multicolumn{4}{|c|}{ Breeds } & \multirow{2}{*}{ Total } \\
\hline & Borane & Arsi & Harar & HF-cross & \\
\hline $2-3 y r s$ & 3 & 3 & 3 & 3 & 12 \\
\hline $4-5$ yrs & 3 & 3 & 3 & 3 & 12 \\
\hline Total & 6 & 6 & 6 & 6 & 24 \\
\hline
\end{tabular}


truck and transported to ELFORA Bishoftu export abattoir. The distance, average speed, total time spent, temperature and relative humidity during travel were recorded as presented in Table 2. Hygrometer and thermometer were used to measure humidity and temperature respectively.

The bulls were stayed in the lairage for $60 \mathrm{hrs}$ with free access to water and natural grass hay and fasted for the last $12 \mathrm{hrs}$. Then the bulls were slaughtered and dressed following the standard procedure of the abattoir.

\subsubsection{Evaluation of Carcass Yield: Carcass Weights and Dressing Percentage}

Commercial and true dressing percentage was evaluated based on the following parameters. Hot carcass weights (HCW) were recorded immediately after slaughter. Edible offal (heart, liver, kidney, digestive organs,) and nonedible offal (skin, head, feet, blood, spleen, lungs, trachea, genitalia, fat deposit) carcass components were weighed and recorded. The main fat component considered in the study includes (scrotal fat, kidney fat, pelvic fat and omental fat) recorded using sensitive balance. The digestive tract was weighed when full and empty in order to compute the weight of intestinal content.

Empty body wieght $(\mathrm{EBW})=$ Slaughterbody weight $(\mathrm{kg})-$ GIT content $(\mathrm{kg})$

Dressing percentage was computed as follow:

$$
\begin{gathered}
\text { CommercialDressing Percentage }(\%)=\frac{\text { Hot Carcass Weight }(\mathrm{kg})}{\text { Slaughter Body Weight }(\mathrm{kg})} \times 100 \\
\text { TrueDressing Percentage }(\%)=\frac{\text { Hot Carcass Weight }(\mathrm{kg})}{\text { Edible Body Weight }(\mathrm{kg})} \times 100
\end{gathered}
$$

Total edible proportion (TEP) was computed as:

$$
\operatorname{TEP}(\mathrm{kg})=\mathrm{SBW}(\mathrm{kg})-(\text { GIT Content }+ \text { hide }+ \text { head }+ \text { feet }+ \text { lung }+ \text { trachea })(\mathrm{kg})
$$

\subsubsection{Evaluation of Carcass Quality: pH, Ribeye Area and Subcutaneous Fat Thickness}

Carcass $\mathrm{pH}$ was measured at $45 \mathrm{~min}$ post-slaughter (pH45). The carcass was kept in cold room at $-4^{\circ} \mathrm{C}$ for $24 \mathrm{hrs}$. The $\mathrm{pH}$ of carcass at $6 \mathrm{hrs}(\mathrm{pH} 6), 12 \mathrm{hrs}(\mathrm{pH} 12)$ and $24 \mathrm{hrs}$ post-slaughter ( $\mathrm{pH} 24)$ were measured using automatic digital

Table 2. Climatic variables, distance and speed and total tame of the journey.

\begin{tabular}{cccc}
\hline Variables & Average & Minimum & Maximum \\
\hline Ambient Temperature $\left({ }^{\circ} \mathrm{C}\right)$ & 25.05 & 21.5 & 27.3 \\
Relative humidity $(\%)$ & 51.85 & 38 & 76 \\
Speed of the truck $(\mathrm{km} / \mathrm{hr})$ & 43.57 & 30 & 70 \\
Distance from HU to Bishotu ELFORA & 462 & & \\
export abattoir $(\mathrm{Km})$ & 14 & & \\
Total time of the journey $(\mathrm{hr})$ & &
\end{tabular}

$\mathrm{Km}=$ kilo meter, $\mathrm{hr}=$ hour, $\mathrm{HU}=$ Haramaya University. 
$\mathrm{pH}$ meter equipped with a penetrating electrode in order to estimate the rate of $\mathrm{PH}$ change and ultimate $\mathrm{PH}$. The $\mathrm{pH}$ was directly measure on the longissimus dorsi muscle (LDM) and semitendinosus muscle by incising the muscle for about $5 \mathrm{~cm}$ depth by using Portable HANNA pH or temperature meter (model number-HI99163).

At $24 \mathrm{hrs}$ postmortem the following measurement were taken; Longissimus dorsi muscle area (Eye-muscle area) and subcutaneous fat thickness (SFT) were determined between the 12th and 13th ribs using a plastic grid for quick measurement of loin eye (Beef) (Model number-AS-234e) graded in inch square for ribeye area and plastic ruler graded in millimeter was used in SFT measurement. These measurements were performed on the right and left sides of the carcass and the values represent their averages.

\subsubsection{Evaluation of Meat Yield and Meat Cuts}

Beef carcasses were split along the axis of symmetry into halves, then across into forequarters and hindquarters again by using meat saw. Forequarter and hindquarter were separated at between 12th and 13th rib. Carcasses were partitioned into nine major primal cuts based on USA meat cut system. Briefly, Beef On the forequarter the chuck, brisket, rib, plate and fore shank. The beef hind quarter: the flank, the long loin, the round and the short loin. All cuts were deboned carefully; bone and meat were weighed and recorded separately using sensitive balance. The meat was not separated from subcutaneous fat. The weight of total internal fats (fats from the kidney, scrotal, pelvic, and heart) were recorded using sensitive balance.

\subsection{Statistical Analysis}

The data were analyzed using General Linear Model (GLM) procedure of Statistical Analysis System [15]. The multiple regression was used for determination of the most suitable model in prediction of the meat yield using live weight, body condition scoring, ribeye area, fat thickness and major primal cuts as explanatory variables to establish regression equations. The model included the main effects of age and breed in determining carcass yield, quality and meat characteristics. The difference among treatment means were tested using Tukeys' test at 0.05 level of significance.

The models used for the analysis were:

To evaluate carcass, non-carcass, meat characteristics and quality the following model was used.

Model I,

$$
Y_{i j k}=\mu+A_{i}+B_{j}+\left(A^{*} B\right)_{i j}+e_{i j k}
$$

where,

$Y_{i j k}=$ Response variable,

$\mu=$ Overall mean,

$A_{i}=$ age effect $(i=2$ level $)$, 
$B_{j}=$ breed effect $(j=4$ level $)$,

$A{ }^{\star} B=$ interaction effect of age and breed,

$e_{i j k}=$ random error.

\section{Model II,}

To calculate the relationships between meat yield and different explanatory variables.

$$
Y_{i}=\alpha+\beta_{1} X_{1}+\beta_{2} X_{2}+\beta_{3} X_{3}+\beta_{4} X_{4}+\beta_{5} X_{5}+\varepsilon
$$

where,

$Y_{i}=$ dependent variable (meat yield),

$\alpha=$ intercept,

$X_{1}, X_{2}, X_{3}, X_{4}$, and $X_{5}=$ independent variable (chuck, rib, plate, tenderloin and round) respectively.

$\beta_{1}, \beta_{2}, \beta_{3}, \beta_{4}$ and $\beta_{5}=$ Partial regression slopes corresponding to the respective independent variable (chuck, rib, plate, tender loin and round) respectively.

$\varepsilon=$ Residual.

Model III,

To calculate the relationships between change in meat yield and live animal condition.

$$
Y_{i}=\alpha+\beta_{1} X_{1}+\beta_{2} X_{2}+\varepsilon
$$

where,

$Y_{i}=$ dependent variable (meat yield),

$\alpha=$ intercept,

$X_{1}$ and $X_{2}=$ independent variable BCS and live weight,

$\beta_{1}$ and $\beta_{2}=$ regression slopes of BCS and live weight,

$\varepsilon=$ Residual.

\section{Results and Discussion}

\subsection{Carcass and Non-Carcass Characteristics}

Effect of breeds and age on live, carcass weight and non-carcass characteristics is presented in Table 3. In the present study, no breed effect was observed on slaughter weight, hot and cold carcass weight. However, [12] and [16] reported that Borana breed had the highest slaughter and carcass weight compared to Harar and Arsi breeds. However, they have indicated the possibility of confinement of the effect of breed with production systems as the bulls was slaughtered being purchased directly from different production systems. In this study, bulls in the $4-5$ years age category had higher $(\mathrm{P}<0.05)$ slaughter weight, hot and cold carcass weight than their counter part. This variation could be due to the development of muscle and fat in animals increase with increasing age. This finding was in consistence with some of previous works of [12] [16] [17] [18] [19].

Dressing Percentage becomes economically important parameter in carcass evaluation, since hot carcass weight is also affected by values of non-carcass 
Table 3. Effect of breeds and age on live, carcass weight and non-carcass characteristics.

\begin{tabular}{|c|c|c|c|c|c|c|c|c|}
\hline \multirow{2}{*}{ Category } & SBW (kg) & HCW (kg) & $\mathrm{CCW}(\mathrm{kg})$ & Sh. Loss (\%) & TEOffal (kg) & TNEP (kg) & CDP (\%) & TDP (\%) \\
\hline & \multicolumn{8}{|c|}{ Mean \pm SE } \\
\hline \multicolumn{9}{|l|}{ Breeds } \\
\hline Arsi & $160.2 \pm 7.9^{\mathrm{a}}$ & $82 \pm 4.8^{\mathrm{a}}$ & $76.6 \pm 4.5^{\mathrm{a}}$ & $6.4 \pm 1.5^{\mathrm{a}}$ & $13.2 \pm 0.5^{\mathrm{ab}}$ & $32.6 \pm 1.1^{\mathrm{b}}$ & $51.1 \pm 0.8^{\mathrm{a}}$ & $79.3 \pm 1.9^{\mathrm{a}}$ \\
\hline Borana & $197.3 \pm 15.8^{\mathrm{a}}$ & $97.5 \pm 9.7^{\mathrm{a}}$ & $91.6 \pm 8.7^{\mathrm{a}}$ & $5.8 \pm 0.9^{\mathrm{a}}$ & $15.9 \pm 1.0^{\mathrm{a}}$ & $39.6 \pm 1.8^{\mathrm{a}}$ & $49.1 \pm 1.2^{\mathrm{a}}$ & $79.8 \pm 1.3^{\mathrm{a}}$ \\
\hline HF-Cross & $186.2 \pm 18.4^{\mathrm{a}}$ & $86.5 \pm 7.9^{\mathrm{a}}$ & $85.0 \pm 8.0^{\mathrm{a}}$ & $1.8 \pm 0.5^{\mathrm{a}}$ & $16.2 \pm 1.5^{\mathrm{a}}$ & $36.5 \pm 1.5^{\mathrm{ab}}$ & $46.6 \pm 1.2^{\mathrm{a}}$ & $76.8 \pm 1.6^{\mathrm{a}}$ \\
\hline Harar & $169.6 \pm 9.3^{\mathrm{a}}$ & $81.3 \pm 3.9^{\mathrm{a}}$ & $77.6 \pm 4.7^{\mathrm{a}}$ & $4.7 \pm 1.4^{\mathrm{a}}$ & $12.5 \pm 0.6^{\mathrm{b}}$ & $35.0 \pm 1.2^{\mathrm{ab}}$ & $48.3 \pm 1.0^{\mathrm{a}}$ & $77.3 \pm 1.8^{\mathrm{a}}$ \\
\hline $\mathrm{P}$-value & NS & NS & NS & NS & $* *$ & $* *$ & NS & NS \\
\hline \multicolumn{9}{|l|}{ Age } \\
\hline $2-3$ yrs & $158.1 \pm 5.9^{\mathrm{b}}$ & $78 \pm 3.2^{\mathrm{b}}$ & $73.5 \pm 3.2^{\mathrm{b}}$ & $5.8 \pm 1.0^{\mathrm{a}}$ & $13.1 \pm 0.4^{\mathrm{b}}$ & $33.9 \pm 1.0^{\mathrm{b}}$ & $49.3 \pm 0.7^{\mathrm{a}}$ & $79.4 \pm 0.8^{\mathrm{a}}$ \\
\hline $4-5 y r s$ & $198.1 \pm 9.9^{\mathrm{a}}$ & $95.6 \pm 5.3^{\mathrm{a}}$ & $92.0 \pm 4.7^{\mathrm{a}}$ & $3.6 \pm 0.7^{\mathrm{a}}$ & $15.9 \pm 0.9^{\mathrm{a}}$ & $38.1 \pm 1.1^{\mathrm{a}}$ & $48.3 \pm 0.9^{\mathrm{a}}$ & $77.2 \pm 1.4^{\mathrm{a}}$ \\
\hline $\mathrm{P}$-value & $* *$ & * & ** & NS & $* *$ & $* *$ & NS & NS \\
\hline Overall & $179.1 \pm 1.0$ & $86.8 \pm 3.5$ & $82.7 \pm 3.4$ & $4.7 \pm 0.6$ & $14.5 \pm 0.5$ & $35.9 \pm 0.8$ & $48.8 \pm 0.6$ & $78.3 \pm 0.8$ \\
\hline Breed * Age & NS & NS & NS & NS & NS & NS & NS & NS \\
\hline $\mathrm{CV}$ & 14.8 & 17.6 & 17.3 & 26.5 & 13.3 & 8.6 & 5.7 & 5.0 \\
\hline
\end{tabular}

Mean values under the same category that bear different superscript letters are significantly different, NS $=\mathrm{P}>0.05,{ }^{* * *}=\mathrm{P}<0.001,{ }^{* *}=\mathrm{P}<0.01$; ${ }^{*}=\mathrm{P}<$ $0.05, \mathrm{SE}=$ standard error of mean, HF-cross = Holstein Frisian crossbred, CV = Coefficient of variation, $\mathrm{kg}=$ kilo gram, SBW = slaughter body weight, $\mathrm{HCW}=$ hot carcass weight, $\mathrm{CCW}=$ cold carcass weight, $\mathrm{SH}$. Loss $=$ shrink loss, $\mathrm{TE}=$ total edible, TNEP $=$ total non-edible portion, $\mathrm{CDP}=$ commertial dressing percentage, $\mathrm{TDP}=$ true dressing percentage.

weight which includes values of economically less important components of the carcass such as head, feet, skin as well as visceral [20]. Especially edible offal is the most economically important components of carcass in Ethiopia as well as almost all over the world. So therefore, it is better if total edible portion of the carcass is considered in calculation of dressing percentage to get actual or true dressing percentage. Commercial (CDP) and True (TDP) dressing percentage were not affected by breeds and age groups in the present result. However, the dressing percentage of Borana breed in the current study was lower than that reported for the same breed reported by [10], who noted 54.78\%, [21] noted $52 \%$ for Ethiopian Borana and $55.7 \%$ for Improved Borana; whereas higher than the value $45.15 \%, 43.9 \%, 47 \%$ and $47.49 \%$ reported by [12] [16] [17] [22] respectively. Dressing percentage of Arsi breed was comparable with the report by [23] which was $51.5 \%$, [24] which was $50.3 \%$ for the same breed. For HF-Crossbred the value was lower than the report by [25] 51.6\% for Guzerat-HF crossbred bulls in brazil. For Harar breed the value obtained in this study was higher than the report by [16]. [10] reported lower dressing percentage for Arado, Barka and Raya cattle breeds slaughtered in Northern part Ethiopia.

Moreover, the overall dressing percentage value in the current study was higher than previous works on similar breeds by [12] and [16] noted $46.38 \%$ and $45.46 \%$ respectively.

Regardless of the significant $(\mathrm{P}<0.05)$ difference in slaughter and hot carcass 
weight, age didn't influence $(\mathrm{P}>0.05)$ dressing percentage. This may be due to similar proportions of carcass to live weight ratio across different age groups since dressing percentage is related to slaughter body weight. This is in line with those previous report by [12] and [26]. Dressing percentage variation may occur as a result of differences on the genotypes, localities and/or conditions of animals [27], sex and age of the animals [11].

Weight loss during carcass chilling is a significant economic consideration for the red meat industry [28]. Chilling loss within $24 \mathrm{hrs}$ was not affected by age and breed in the current study. Similarly [25] reported no difference among breed on cold shrink loss. According to [18] chilling loss was affected by the level of subcutaneous fat thickness. The subcutaneous fat thickness, which works as an insulator, avoiding losses by dehydration does not influenced by breeds and age in this study as presented in (Table 5). Therefore, carcasses with comparable fat content have almost similar losses during chilling process [25]. The overall chilling loss percentage in this study was higher than those report by [29] noted $1.36 \%$ for Boss Taurus beef chilled for 24 hrs, [25] 3.0\% for Guzerat-HF crossbred bulls in brazil. The weight loss of beef carcasses during the first $24 \mathrm{hrs}$ was reported to range from $1.1 \%$ to $2.1 \%$ for Boss Taurus in the UK [30], $0.4 \%$ to $2.2 \%$ in Brazil [31].

The superiority $(\mathrm{P}<0.01)$ of total edible offal $($ Heart + kidney + liver + stomach + largeintestine + small intestine) of HF-Crossbred and Borana bulls in relation to Harar bulls were observed in the present study, whereas intermediate value was recorded for Arsi bulls. In addition to carcass cut, total edible offal is also another economically important portion of non-carcass output for wholesalers and retailers. Therefore, the wholesalers and retailers desire a carcass that yields more components to be utilized. The finding was in agreement with [32] [33] finding which reported higher edible portion would provide minor amounts of losses and higher percentages of pieces that allow overall edible portion and highest commercial value. The older age group $(4-5$ years $)$ the higher $(\mathrm{P}<0.01)$ total edible offal and total non-edible portion. This might be attributed to the increase in size of animals' body organs and different body parts with increasing age.

Considering total non-edible portion (Head with horn, Feet, Blood, Spleen, Pancreas, Trachea with lung, Penis, Testicle, Bladder, Gallbladder, and Hide), Borana bulls showed a significantly higher $(\mathrm{P}<0.01)$ weight than Arsi bulls while Harar and HF-Crossbred were intermediate. This may be due to heavier body conformation in Borana bulls, the higher carcass and non-carcass portion proportionally. This finding was in agreement with [34] and [35] who had reported that animals with larger body had larger body organs.

\subsection{Meat Yield Percentage}

Effect of breed and age on meat yield percentage are precented in Table 4. Meat yield percent was significantly $(\mathrm{P}<0.0001)$ influenced by breed. This is in agreement with the report of [10] for Arado, Raya, Barka and Borana cattle. In 
Table 4. Effect of age and breed on meat yield percentage and ribeye area.

\begin{tabular}{|c|c|c|c|}
\hline \multirow{3}{*}{ Category } & \multicolumn{2}{|c|}{ Carcass proportion (\%) } & \multirow{2}{*}{$\begin{array}{l}\text { Ribeye area } \\
\quad\left(\text { inch }^{2}\right)\end{array}$} \\
\hline & Meat + fat & Bone & \\
\hline & \multicolumn{3}{|c|}{$($ Mean \pm SE $)$} \\
\hline \multicolumn{4}{|l|}{ Breeds } \\
\hline Arsi & $78.1 \pm 0.26^{\mathrm{a}}$ & $21.9 \pm 0.26^{\mathrm{b}}$ & $5.60 \pm 3.33$ \\
\hline Borana & $77.0 \pm 0.82^{\mathrm{a}}$ & $22.99 \pm 0.85^{\mathrm{b}}$ & $6.23 \pm 5.26$ \\
\hline HF-Cross & $72.8 \pm 0.67^{\mathrm{b}}$ & $27.18 \pm 0.67^{\mathrm{a}}$ & $5.28 \pm 5.51$ \\
\hline Harar & $77.2 \pm 0.64^{\mathrm{a}}$ & $22.71 \pm 0.64^{\mathrm{b}}$ & $6.05 \pm 4.58$ \\
\hline Sig. & $* * *$ & $* * *$ & NS \\
\hline \multicolumn{4}{|l|}{ Age } \\
\hline $2-3 \mathrm{yrs}$ & $75.98 \pm 0.82^{\mathrm{a}}$ & $24.01 \pm 0.82^{\mathrm{a}}$ & $5.15 \pm 2.27^{\mathrm{b}}$ \\
\hline $4-5 \mathrm{yrs}$ & $76.60 \pm 0.67^{\mathrm{a}}$ & $23.39 \pm 0.67^{\mathrm{a}}$ & $6.42 \pm 3.24^{\mathrm{a}}$ \\
\hline Sig. & Ns & Ns & $* *$ \\
\hline Overall & $76.2 \pm 0.52$ & $23.7 \pm 0.52$ & $5.791 \pm 2.34$ \\
\hline Breed $^{*}$ Age & * & Ns & Ns \\
\hline
\end{tabular}

Mean values under the same category that bear different superscript letters are significantly different, Ns = $\mathrm{P}>0.05,{ }^{* *}=\mathrm{P}<0.001,{ }^{* *}=\mathrm{P}<0.01 ;^{*}=\mathrm{P}<0.05, \mathrm{SE}=$ standard error of mean, HF-cross $=$ Holstein Frisian crossbred.

the current result HF-Crossbred bulls has relatively lower (72.8\%) meat yield compared to the three breed (Arsi, Borana and Harar) bulls in which the latter were statistically similar. Meat yield percent did not influenced by age. The overall yield percent (76.2\%) in the current finding was higher than those previouse finding by [12] noted that yield percent were ranged between $35 \%$ to $60 \%$ for the same breed with the current finding, [10] Mummed and Webb (2019) also reported $67.81 \%$ yield percentage for Arado, Raya and Barka breed, [36] reported for Nguni (72.5\%) and Tuli (73\%) cattle in South Africa. Generaly the comparision of the currentresult with the [12] finding showed the importance of concentrate supplementation to improves meat yield percent from bulls.

Ribeye area is the most useful technique used to indicate the muscle amount obtained from the total carcass of meat animals. Breed has no significant $(\mathrm{P}>$ 0.05 ) influence on ribeye area but the older age group ( $4-5$ years) attained higher $(\mathrm{P}<0.01)$ ribeye areas than $2-3$ years old bulls. This may be due to as animals increase in age muscularity and cut yield also increased. This is in line with the previous report by [12] [37] [38].

Breed by age interaction effected meat yield percentage as presented in Figure 1. The figure shows that there was linear rate of meat yield increment from two to five years old bulls of Borana, Harar and HF-Crossbred. Greater rate of yield percent increment was observed for the HF-Crossbred which was 1.98 followed by Borana and Harar with 1.1 and 0.1 rate of increment respectively as age advanced. But Arsi bulls attain the highest (78\%) yield at an early age but decrease 


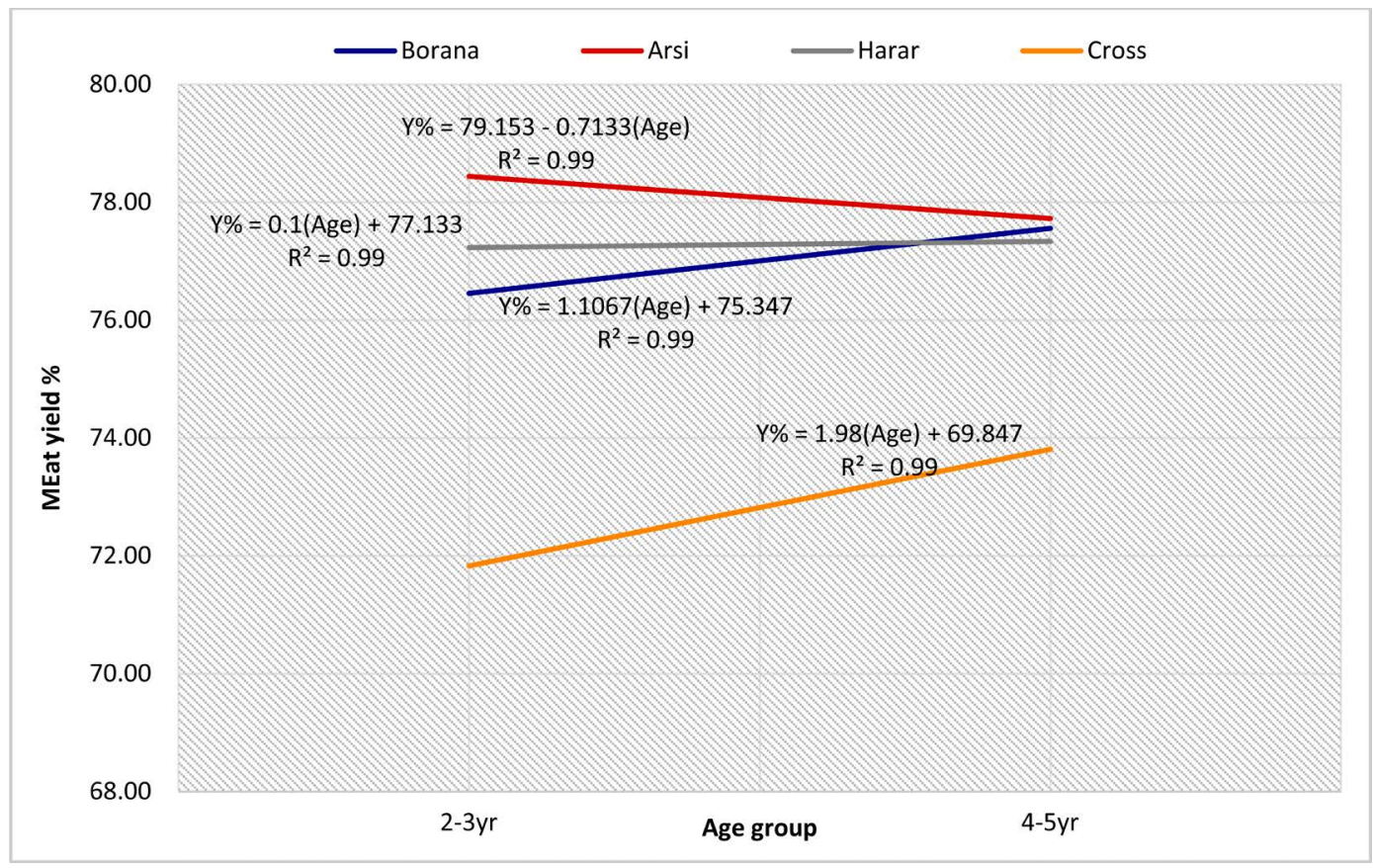

Figure 1. Age by breed interaction on meat yield percent of Arsi, Boran, Harar and HF-Crossbred bulls.

by 0.713 rate as age of animals advanced by one digit. This is corroborated by [12] who reorted that rate of yield percent decreased by 0.93 for the Arsi breed as the age advanced from one category to the other. This variation in meat yield percent could be due to variation in live weight of different breeds in different age categories. This is in line with the report of [10] for Arado, Barka and Rayya cattle in Ethiopia, [39] for Angus, limousine and Wagyu cattle in Australia. Generally, this figure shows that supplementing Arsi bulls with age of above five years old is not economically profitable in terms of meat yield percentage as compared with Borana, Harar and HF-Crossbred bulls.

\subsection{Effect of Age and Breed on Fat Characteristics and Ribeye Area}

In the current study, scrotal fat, kidney fat, heart fat, omental fat and subcutaneous fat thickness were not affected by age and breeds as shown in Table 5 . This is in agreement with the finding of [12] who reported that there were no breed effects on kidney, heart fat and subcutaneous fat thickness for the same breed to the current study. Similarly, [25] also reported no breed effect for subcutaneous fat thickness of the Guzerat and their HF-crossbred bulls in Brazil, [22] also reported that no breed effect was observed in heart fat, subcutaneous fat thickness and ribeye area for Borana and Kereyu breed bulls. In contrast to the current finding [22] reported that Borana bulls recorded significantly higher $(\mathrm{P}<0.05)$ pelvic fat, scrotal fat and kidney fat values than Kereyu bulls, [17] also reported that age significantly influence scrotal fat, kidney fat, heart fat, omental fat and subcutaneous fat thickness in Borana bulls. The overall weight record of kidney and heart fat in the current study were higher than 0.21 and $0.17 \mathrm{~kg}$ 
Table 5. Effect of age and breed on fat characteristics.

\begin{tabular}{|c|c|c|c|c|c|c|}
\hline \multirow[t]{2}{*}{ Category } & $\begin{array}{l}\text { Scrotal fat } \\
\quad(\mathrm{kg})\end{array}$ & $\begin{array}{c}\text { Kidney fat } \\
\quad(\mathrm{kg})\end{array}$ & $\begin{array}{l}\text { Pelvic fat } \\
(\mathrm{kg})\end{array}$ & $\begin{array}{l}\text { Heart fat } \\
\quad(\mathrm{kg})\end{array}$ & $\begin{array}{l}\text { Omental fat } \\
(\mathrm{kg})\end{array}$ & SFT $(\mathrm{mm})$ \\
\hline & \multicolumn{6}{|c|}{ Mean \pm SE } \\
\hline \multicolumn{7}{|l|}{ Breeds } \\
\hline Arsi & $0.48 \pm 0.04$ & $0.61 \pm 0.05$ & $0.27 \pm 0.03^{\mathrm{ab}}$ & $0.52 \pm 0.06$ & $0.82 \pm 0.11$ & $6.25 \pm 1.18$ \\
\hline Borana & $0.67 \pm 0.12$ & $0.61 \pm 0.13$ & $0.42 \pm 0.06^{\mathrm{a}}$ & $0.62 \pm 0.09$ & $1.12 \pm 0.22$ & $4.0 \pm 1.09$ \\
\hline HF-Cross & $0.44 \pm 0.07$ & $0.56 \pm 0.08$ & $0.21 \pm 0.04^{\mathrm{b}}$ & $0.41 \pm 0.05$ & $0.8 \pm 0.13$ & $3.91 \pm 0.84$ \\
\hline Harar & $0.5 \pm 0.03$ & $0.57 \pm 0.09$ & $0.27 \pm 0.05^{\mathrm{ab}}$ & $0.58 \pm 0.07$ & $0.78 \pm 0.06$ & $4.25 \pm 0.77$ \\
\hline $\mathrm{P}$-value & NS & NS & * & NS & NS & NS \\
\hline \multicolumn{7}{|l|}{ Age } \\
\hline $2-3 y r s$ & $0.46 \pm 0.03$ & $0.55 \pm 0.06$ & $0.31 \pm 0.04$ & $0.52 \pm 0.05$ & $0.83 \pm 0.11$ & $3.62 \pm 0.52$ \\
\hline $4-5$ yrs & $0.58 \pm 0.06$ & $0.59 \pm 0.06$ & $0.28 \pm 0.03$ & $0.56 \pm 0.05$ & $0.93 \pm 0.09$ & $5.58 \pm 0.78$ \\
\hline $\mathrm{P}$-value & NS & NS & NS & NS & NS & NS \\
\hline Overall & $0.52 \pm 0.04$ & $0.57 \pm 0.04$ & $0.29 \pm 0.02$ & $0.53 \pm 0.03$ & $0.88 \pm 0.07$ & $4.6 \pm 0.50$ \\
\hline Breed $^{*}$ Age & NS & NS & NS & NS & NS & NS \\
\hline $\mathrm{CV}$ & 36.4 & 43.9 & 37.4 & 33.8 & 40.5 & 40.7 \\
\hline
\end{tabular}

Mean values under the same category that bear different superscript letters are significantly different, $\mathrm{ns}=$ $\mathrm{P}>0.05,{ }^{* *}=\mathrm{P}<0.001,{ }^{* *}=\mathrm{P}<0.01{ }^{*}=\mathrm{P}<0.05, \mathrm{SE}=$ standard error of mean, HF-cross $=$ Holstein Frisian crossbred, $\mathrm{CV}=$ Coefficient of variation, $\mathrm{kg}=$ kilo gram, $\mathrm{SFT}=$ subcutaneous fat thickness, $\mathrm{mm}=$ millimeter.

respectively reported by [12] for the same breeds finished in different production systems to the current study. The overall subcutaneous fat thickness value in this study was higher than the value $(0.45 \mathrm{~mm}$ to $0.96 \mathrm{~mm})$ reported by [12] for the same breeds to the current study, $(3.3 \mathrm{~mm}$ to $4.3 \mathrm{~mm})$ value reported by [27] for Afar bulls, $3.75 \mathrm{~mm}$ reported by [22] for Borana and Kereyu bulls, but lower than $4.82 \mathrm{~mm}$ value reported by [25] for Guzerat and their HF-crossbred bulls in Brazil. The different in the report in this respect can be associated with feeding condition before slaughter. The overall scrotal and omental fat recorded in this study were lower than $0.73 \mathrm{~kg}$ and $1.2 \mathrm{~kg}$ respectively as reported by [17] for Borana bulls of 2 and 4 years old. Similarly [22] reported $1.01 \mathrm{~kg}$ scrotal fat for Borana and Kereyu bulls.

Borana breed under similar management conditions deposited significantly higher $(\mathrm{P}<0.05)$ pelvic fat than HF-Crossbred bulls whereas Harar and Arsi bulls deposited intermediate value. This is in agreement with the report of [22] that Borana bulls significantly higher $(\mathrm{P}<0.05)$ pelvic fat than Kereyu bulls under similar management. In contrast to the current result [12] reported that there was no significant difference $(\mathrm{P}>0.05)$ in pelvic fat content among the breeds.

\subsection{Correlation between Meat Yield and Fat Characteristics}

According to the result presented in Table 6 scrotal fat was strongly $(\mathrm{P}<0.0001)$ 
Table 6. Correlation between meat yield and fat characteristics of Arsi, Borana, Harar and HF-Crossbred bulls.

\begin{tabular}{|c|c|c|c|c|c|c|c|c|}
\hline & SF & $\mathrm{KF}$ & PF & OF & $\mathrm{TF}$ & REA & SFT & MY \\
\hline SF & 1 & $0.07^{\mathrm{ns}}$ & $0.18^{\mathrm{ns}}$ & $0.26^{\mathrm{ns}}$ & $0.49^{*}$ & $0.61^{* *}$ & $0.37^{\mathrm{ns}}$ & $0.72^{* * *}$ \\
\hline $\mathrm{KF}$ & & 1 & $0.26^{\mathrm{ns}}$ & $0.61^{\star *}$ & $0.73^{* * *}$ & $0.22^{\mathrm{ns}}$ & $-0.29^{\mathrm{ns}}$ & $0.11^{\mathrm{ns}}$ \\
\hline $\mathrm{PF}$ & & & 1 & $0.43^{\star}$ & $0.58^{* *}$ & $0.21^{\mathrm{ns}}$ & $-0.05^{\mathrm{ns}}$ & $0.12^{\text {ns }}$ \\
\hline $\mathrm{OF}$ & & & & 1 & $0.91^{\star * *}$ & $0.36^{\mathrm{ns}}$ & $0.15^{\mathrm{ns}}$ & $0.36^{\text {ns }}$ \\
\hline $\mathrm{TF}$ & & & & & 1 & $0.49^{\star}$ & $0.08^{\mathrm{ns}}$ & $0.46^{*}$ \\
\hline REA & & & & & & 1 & $0.45^{\star}$ & $0.75^{\star * *}$ \\
\hline SFT & & & & & & & 1 & $0.51^{* *}$ \\
\hline MY & & & & & & & & 1 \\
\hline
\end{tabular}

$\mathrm{SF}=$ scrotal fat, $\mathrm{KF}=$ kidney fat, $\mathrm{PF}=$ pelvic fat, $\mathrm{OF}=$ omental fat, $\mathrm{TF}=$ total fat, $\mathrm{REA}=$ ribeye area, $\mathrm{SFT}=$ subcutaneous fat thickness, $\mathrm{MY}=$ meat yield, $\mathrm{ns}=\mathrm{P}>0.05,{ }^{* *}=\mathrm{P}<0.001,{ }^{* *}=\mathrm{P}<0.01{ }^{*}=\mathrm{P}<0.05$.

correlated with meat yield $(r=0.72)$, and also highly $(\mathrm{P}<0.001)$ correlated with ribeye area $(r=0.61)$. Kidney fat was strongly $(\mathrm{P}<0.0001)$ correlated with total fat $(r=0.73)$, and omental fat $(r=0.61)$, while negatively correlated with subcutaneous fat thickness. Pelvic fat somewhat highly correlated (0.01) with total fat $(r=0.58)$ and omental fat $(r=0.43)$, while negatively correlated with subcutaneous fat thickness. Omental fat has strong $(\mathrm{P}<0.0001)$ correlation with total fat. Ribeye area has strong $(\mathrm{P}<0.0001)$ correlation with meat yield. Subcutaneous fat thickness had shown strong $(\mathrm{P}<0.001)$ correlation with meat yield. Generally, meat yield was strongly correlated with scrotal, subcutaneous fat and ribeye area. The relative proportionality of fat thickness with carcass weight may be due to the slight increment in deposition of fat tissue as cattle advances with body weight. On the other hand, the relative proportions of specific tissues change as the animal matures, typified by reductions in the growth rates of muscle and bone and increasing rates of fat deposit [18] [40] [41].

The result of this research was in agreement to the report of [42] [43] that the fat thickness and ribeye area on the 12th rib resulting highly significant correlation $(\mathrm{P}<0.0001)$ with content of meat yield. This research created the best multiple regression equation to predict meat yield based on fat thickness and ribeye area as follows:

$$
\mathrm{MY}=8.49+0.41(\mathrm{REA})+0.65(\mathrm{SFT})
$$

having $\mathrm{R}^{2}=61 \%$, $\mathrm{RMSE}=4.69, \mathrm{P}<0.0001$.

Where, $\mathrm{MY}=$ meat yield in $\mathrm{Kg}, \mathrm{REA}=$ ribeye area in inch square, $\mathrm{SFT}=$ subcutaneous fat thickness in millimeter, RMSE $=$ Root mean square error, $\mathrm{R}^{2}=$ coefficient of determination.

\subsection{Meat Yield, Percentage, Primal Meat Cuts and Proportion of Bone Component}

The average meat yields from forequarter and hindquarter weight were pre- 
sented in Table 7. Breed did not influence fore and hindquarter weight of meat yield while bulls in $4-5$ years old has significantly $(\mathrm{P}<0.01)$ heavier meat yield than 2 - 3 years old bulls, particularly, in chuck, Rib, Plate, Tenderloin, Top sirloin, fore- and hindquarter. The heavier fore- and hindquarter in older age bulls ( 4 - 5 years) could be due to heavier live and carcass weight of bulls than $2-3$ years age category. In line with the current finding, some research findings reported that a heavier live and carcass weights were reflected in heavier primal cuts for Borana, Arsi, Harar breed [10] [12] [17]. The mean value of meat weight from each carcass cut of forequarter was not affected by breed except for Fore shank. The weight of meat cut from HF-Crossbred was relatively heavier $(\mathrm{P}<$ 0.05) than the cut from Arsi bulls whereas Borana and Harar recorded intermediate value for Fore-shank.

The mean Sirloin from HF-Cross was significantly $(\mathrm{P}<0.05)$ heavier than Harar but the reverse is true for Top-sirloin, whereas Arsi and Borana attain intermediate weight for both Sirloin and Top-sirloin. Borana yielded significantly high $(\mathrm{P}<0.01)$ weight of Bottom-sirloin than Arsi and Harar. In line to the current result, [12] reported better performance of Bottom-sirloin for Borana breed than Arsi and Harar.

The proportion of carcass component and meat yield from Arsi, Borana, Cross

Table 7. Effect of age and breeds of Arsi, Borana, Cross and Harar bulls on weight of boneless meat from each primal cuts.

\begin{tabular}{|c|c|c|c|c|c|c|c|c|c|}
\hline \multirow{2}{*}{$\begin{array}{l}\text { Primal cuts } \\
\quad(\mathrm{kg})\end{array}$} & \multicolumn{5}{|c|}{ Breeds } & \multicolumn{3}{|c|}{ Age } & \multirow{2}{*}{ Overall } \\
\hline & Arsi & Borana & HF-Cross & Harar & Sig. & $2-3 \mathrm{yr}$ & $4-5 \mathrm{yr}$ & Sig. & \\
\hline & \multicolumn{4}{|c|}{ Mean \pm SE } & \multicolumn{4}{|c|}{ Mean \pm SE } & Mean \pm SE \\
\hline Fore quarter & $14.16 \pm 1.47$ & $15.95 \pm 2.0$ & $13.53 \pm 2.2$ & $13.58 \pm 1.09$ & Ns & $11.62 \pm 0.82^{\mathrm{b}}$ & $16.87 \pm 1.02^{\mathrm{a}}$ & * & $14.25 \pm 0.84$ \\
\hline Chuck & $8.9 \pm 0.89$ & $10.63 \pm 1.40$ & $8.5 \pm 1.64$ & $8.83 \pm 0.58$ & Ns & $7.6 \pm 0.7^{b}$ & $10.83 \pm 0.69^{\mathrm{a}}$ & $* *$ & $9.21 \pm 0.58$ \\
\hline Brisket & $1.96 \pm 0.96$ & $1.00 \pm 0.14$ & $0.966 \pm 0.20$ & $1 \pm 0.19$ & Ns & $0.79 \pm 0.1$ & $1.67 \pm 0.46$ & Ns & $1.23 \pm 0.25$ \\
\hline Rib & $1.98 \pm 0.19$ & $2.2 \pm 0.28$ & $1.98 \pm 0.29$ & $2.1 \pm 0.37$ & Ns & $1.71 \pm 0.13^{\mathrm{b}}$ & $2.4 \pm 0.19^{\mathrm{a}}$ & * & $2.0 \pm 0.13$ \\
\hline Plate & $0.56 \pm 0.06$ & $0.75 \pm 0.13$ & $0.66 \pm 0.07$ & $0.56 \pm 0.12$ & Ns & $0.51 \pm 0.02^{\mathrm{b}}$ & $0.75 \pm 0.08^{\mathrm{a}}$ & * & $0.63 \pm 0.05$ \\
\hline Fore shank & $0.8 \pm 0.08^{\mathrm{b}}$ & $1.35 \pm 0.15^{\mathrm{ab}}$ & $1.41 \pm 0.2^{\mathrm{a}}$ & $0.88 \pm 0.14^{\mathrm{ab}}$ & * & $1.0 \pm 0.08$ & $1.22 \pm 0.16$ & $\mathrm{Ns}$ & $1.11 \pm 0.09$ \\
\hline Hind quarter & $19.71 \pm 0.79$ & $23.36 \pm 1.67$ & $20.58 \pm 1.74$ & $20.65 \pm 0.83$ & Ns & $19.22 \pm 0.62^{\mathrm{b}}$ & $22.93 \pm 0.98^{\mathrm{a}}$ & $* *$ & $21.07 \pm 0.68$ \\
\hline Flank & $0.6 \pm 0.13$ & $0.73 \pm 0.13$ & $0.81 \pm 0.14$ & $0.68 \pm 0.11$ & Ns & $0.65 \pm 0.08$ & $0.76 \pm 0.09$ & Ns & $0.71 \pm 0.06$ \\
\hline Short Loin & $2.0 \pm 0.2$ & $2.9 \pm 0.45$ & $2.06 \pm 0.3$ & $1.86 \pm 0.12$ & Ns & $1.91 \pm 0.13$ & $2.51 \pm 0.28$ & Ns & $2.20 \pm 0.16$ \\
\hline Sirloin & $1.91 \pm 0.13^{\mathrm{ab}}$ & $2.2 \pm 0.29^{\mathrm{ab}}$ & $2.88 \pm 0.39^{\mathrm{a}}$ & $1.75 \pm 0.13^{\mathrm{b}}$ & * & $2.12 \pm 0.24$ & $2.25 \pm 0.19$ & Ns & $2.18 \pm 0.15$ \\
\hline Tender Loin & $0.76 \pm 0.08$ & $1.2 \pm 0.16$ & $0.93 \pm 0.14$ & $0.86 \pm 0.11$ & Ns & $0.79 \pm 0.06^{\mathrm{b}}$ & $1.09 \pm 0.11^{\mathrm{a}}$ & * & $0.94 \pm 0.06$ \\
\hline Top Sirloin & $3.71 \pm 0.35^{\mathrm{ab}}$ & $4.01 \pm 0.47^{\mathrm{ab}}$ & $2.88 \pm 0.44^{\mathrm{b}}$ & $4.41 \pm 0.23^{\mathrm{a}}$ & * & $3.33 \pm 0.34^{\mathrm{b}}$ & $4.18 \pm 0.20^{\mathrm{a}}$ & * & $3.75 \pm 0.21$ \\
\hline Bottom Sirloin & $1.55 \pm 0.14^{\mathrm{b}}$ & $2.46 \pm 0.32^{\mathrm{a}}$ & $2.25 \pm 0.17^{\mathrm{a}}$ & $1.95 \pm 0.18^{\mathrm{ab}}$ & $* *$ & $1.78 \pm 0.12^{\mathrm{b}}$ & $2.32 \pm 0.18^{\mathrm{a}}$ & $* *$ & $2.05 \pm 0.12$ \\
\hline Round & $8.43 \pm 0.27$ & $8.63 \pm 0.43$ & $7.48 \pm 0.56$ & $8.01 \pm 0.46$ & Ns & $7.62 \pm 0.26^{\mathrm{b}}$ & $8.65 \pm 0.30^{\mathrm{a}}$ & * & $8.14 \pm 0.22$ \\
\hline Hind Shank & $0.78 \pm 0.10$ & $1.23 \pm 0.15$ & $1.26 \pm 0.22$ & $1.06 \pm 0.11$ & Ns & $1.00 \pm 0.08$ & $1.16 \pm 0.14$ & Ns & $1.08 \pm 0.08$ \\
\hline
\end{tabular}

Mean values under the same category that bear different superscript letters are significantly different, Ns $=\mathrm{P}>0.05,{ }^{* *}=\mathrm{P}<0.001,{ }^{* *}=\mathrm{P}<0.01{ }^{*}=\mathrm{P}<$ $0.05, \mathrm{SE}=$ standard error of mean, HF-cross $=$ Holstein Frisian crossbred. 
and Harar breeds are presented in Table 8 . There is no significant difference $(\mathrm{P}>0.05)$ concerning meat accumulation on all primal cut except on chuck and rib between the four experimental breeds in the current study. HF-Crossbred bulls accumulated lower $(\mathrm{P}<0.01)$ meat in both chuck and rib primal cut than Arsi, Borana and Harar bulls. Similarly, higher $(\mathrm{P}<0.01)$ total bone proportion

Table 8. Proportion of carcass components and meat yield of Arsi, Borana, HF-Cross and Harar bulls.

\begin{tabular}{|c|c|c|c|c|c|c|c|}
\hline \multirow{3}{*}{ Primal cut } & \multirow{3}{*}{$\begin{array}{c}\text { Components } \\
\text { proportion (\%) }\end{array}$} & \multicolumn{5}{|c|}{ Breeds } & \multirow{3}{*}{ Overall } \\
\hline & & Arsi & Borana & HF-Cross & Harar & \multirow{2}{*}{ Sig. } & \\
\hline & & \multicolumn{4}{|c|}{ Mean \pm SE } & & \\
\hline \multirow{3}{*}{ Chuck } & Meat & $78.26 \pm 1.55^{\mathrm{a}}$ & $76.44 \pm 1.78^{\mathrm{a}}$ & $69.01 \pm 1.74^{\mathrm{b}}$ & $77.19 \pm 0.65^{\mathrm{a}}$ & $* *$ & $75.22 \pm 1.03$ \\
\hline & Bone & $21.73 \pm 1.55^{\mathrm{b}}$ & $23.56 \pm 1.78^{\mathrm{b}}$ & $30.98 \pm 1.74^{\mathrm{a}}$ & $22.80 \pm 0.65^{\mathrm{b}}$ & $* *$ & $24.77 \pm 1.03$ \\
\hline & Meat yield & $25.99 \pm 1.76$ & $26.67 \pm 1.03$ & $23.84 \pm 2.84$ & $25.92 \pm 0.95$ & $\mathrm{~ns}$ & $25.61 \pm 0.87$ \\
\hline \multirow{3}{*}{ Brisket } & Meat & $68.68 \pm 5.10$ & $66.45 \pm 1.95$ & $58.72 \pm 4.05$ & $60.72 \pm 5.85$ & $\mathrm{~ns}$ & $63.64 \pm 2.25$ \\
\hline & Bone & $31.31 \pm 5.10$ & $33.55 \pm 1.95$ & $41.28 \pm 4.05$ & $39.27 \pm 5.85$ & ns & $36.35 \pm 2.25$ \\
\hline & Meat yield & $5.54 \pm 2.41$ & $2.53 \pm 0.29$ & $2.71 \pm 0.29$ & $2.85 \pm 0.49$ & ns & $3.41 \pm 0.63$ \\
\hline \multirow{3}{*}{ Rib } & Meat & $65.7 \pm 1.83^{\mathrm{a}}$ & $68.03 \pm 2.36^{\mathrm{a}}$ & $56.48 \pm 2.11^{\mathrm{b}}$ & $66.94 \pm 1.25^{\mathrm{a}}$ & $\star *$ & $64.29 \pm 1.31$ \\
\hline & Bone & $34.3 \pm 1.83^{\mathrm{b}}$ & $31.96 \pm 2.36^{\mathrm{b}}$ & $43.51 \pm 2.11^{\mathrm{a}}$ & $33.05 \pm 1.25^{\mathrm{b}}$ & $* *$ & $35.70 \pm 1.31$ \\
\hline & Meat yield & $5.68 \pm 0.25$ & $5.52 \pm 0.37$ & $5.72 \pm 0.44$ & $6.05 \pm 0.76$ & ns & $5.74 \pm 0.23$ \\
\hline \multirow{3}{*}{ Plate } & Meat & $53.84 \pm 4.56$ & $51.14 \pm 3.71$ & $50.32 \pm 2.92$ & $44.59 \pm 7.32$ & ns & $49.97 \pm 2.39$ \\
\hline & Bone & $46.15 \pm 4.56$ & $48.85 \pm 3.71$ & $49.67 \pm 2.92$ & $55.40 \pm 7.32$ & $\mathrm{~ns}$ & $50.02 \pm 0.22$ \\
\hline & Meat yield & $1.67 \pm 0.10$ & $1.89 \pm 0.15$ & $1.97 \pm 0.09$ & $1.58 \pm 0.31$ & ns & $1.78 \pm 0.09$ \\
\hline \multirow{3}{*}{ Fore shank } & Meat & $57.32 \pm 6.48$ & $56.22 \pm 3.39$ & $54.38 \pm 1.69$ & $50.55 \pm 3.06$ & ns & $54.62 \pm 1.96$ \\
\hline & Bone & $42.67 \pm 6.48$ & $43.77 \pm 3.39$ & $45.61 \pm 1.69$ & $49.45 \pm 3.06$ & ns & $45.37 \pm 1.96$ \\
\hline & Meat yield & $2.36 \pm 0.25^{\mathrm{a}}$ & $3.4 \pm 0.17^{\mathrm{ab}}$ & $4.25 \pm 0.52^{\mathrm{a}}$ & $2.61 \pm 0.40^{\mathrm{b}}$ & * & $3.14 \pm 0.22$ \\
\hline \multirow{3}{*}{ Flank } & Meat & $100 \pm 0.00$ & $100 \pm 0.0$ & $100 \pm 0.00$ & $100 \pm 0.00$ & $\mathrm{~ns}$ & $100 \pm 0.00$ \\
\hline & Bone & 0 & 0 & 0 & 0 & ns & 0 \\
\hline & Meat yield & $1.81 \pm 0.46$ & $1.87 \pm 0.26$ & $2.34 \pm 0.18$ & $2.01 \pm 0.31$ & ns & $2.01 \pm 0.15$ \\
\hline \multirow{3}{*}{$\begin{array}{l}\text { Loin(short, sir, } \\
\text { tender, top and } \\
\text { bottom Loin) }\end{array}$} & Meat & $91.71 \pm 0.46$ & $91.85 \pm 0.94$ & $90.62 \pm 1.01$ & $92.91 \pm 0.52$ & ns & $91.77 \pm 0.39$ \\
\hline & Bone & $8.28 \pm 0.46$ & $8.14 \pm 0.94$ & $9.37 \pm 1.01$ & $7.08 \pm 0.52$ & $\mathrm{~ns}$ & $8.22 \pm 0.39$ \\
\hline & Meat yield & $29.29 \pm 1.18$ & $32.26 \pm 0.94$ & $32.82 \pm 2.00$ & $32.02 \pm 0.55$ & ns & $31.30 \pm 0.66$ \\
\hline \multirow{3}{*}{ Round } & Meat & $76.97 \pm 0.99$ & $74.45 \pm 1.70$ & $73.99 \pm 3.71$ & $75.35 \pm 1.80$ & $\mathrm{~ns}$ & $75.19 \pm 1.09$ \\
\hline & Bone & $23.02 \pm 0.99$ & $25.55 \pm 1.70$ & $26.00 \pm 3.71$ & $24.64 \pm 1.80$ & $\mathrm{~ns}$ & $24.80 \pm 1.09$ \\
\hline & Meat yield & $25.19 \pm 1.23$ & $22.70 \pm 1.88$ & $22.71 \pm 1.82$ & $23.73 \pm 1.19$ & $\mathrm{~ns}$ & $23.58 \pm 0.87$ \\
\hline \multirow{3}{*}{ Hind Shank } & Meat & $47.87 \pm 5.02$ & $52.8 \pm 2.80$ & $49.13 \pm 2.99$ & $53.14 \pm 2.77$ & ns & $50.73 \pm 1.71$ \\
\hline & Bone & $52.12 \pm 5.02$ & $47.2 \pm 2.80$ & $50.86 \pm 2.99$ & $46.85 \pm 2.77$ & ns & $49.26 \pm 1.71$ \\
\hline & Meat yield & $2.42 \pm 0.37$ & $3.12 \pm 0.32$ & $3.65 \pm 0.32$ & $3.20 \pm 0.38$ & ns & $3.1 \pm 0.18$ \\
\hline
\end{tabular}

Mean values under the same category that bear different superscript letters are significantly different, $\mathrm{ns}=\mathrm{P}>0.05$, ${ }^{* *}=\mathrm{P}<$ $0.001{ }^{* *}=\mathrm{P}<0.01 ;^{*}=\mathrm{P}<0.05, \mathrm{SE}=$ standard error of mean, HF-cross $=$ Holstein Frisian crossbred. 
were observed for HF-Crossbreed in chuck and rib primal. There is no significant difference $(\mathrm{P}>0.05)$ concerning meat yield percentage of each primal cut from the carcass except for Fore shank. Higher $(\mathrm{P}<0.05)$ meat yield was observed for HF-Crossbreed in case of fore shank percentage from whole carcass.

The prediction equations to estimate meat yield from live body weight, body condition score and some of major primal cuts are presented in Table 9. Meat yield can be effectively predicted from live animal traits like live weight and body condition score with coefficient determination $\left(\mathrm{R}^{2}\right)$ of $89.56 \%$. Chuck, rib, plate, tenderloin and round were with the accuracy of prediction $84.08 \%, 32.86 \%$, $67.33 \%, 71.81 \%$ and $59.23 \%$, respectively. The value of coefficient of determination $\left(\mathrm{R}^{2}\right)$ increased as more primal cuts are added to the regression equation (94.78\%). The higher $\mathrm{R}^{2}$ value and smaller MSE attained showed good meat yield prediction equation.

\subsection{Rate of $\mathrm{pH}$ Decline}

The $\mathrm{pH}$ value has a significant impact on the color, shelf life, taste, microbiological stability, yield and texture of meat and meat products and is, therefore, important for meat quality evaluation [44]. MSA research has found beef with $\mathrm{pH}$ levels above 5.70 to be of lower and more variable eating quality. Accordingly, 5.70 has been set as the maximum $\mathrm{pH}$ level for MSA grading. In line with eating quality, the acceptable range of $\mathrm{pH}$ was 5.30 - 5.70 [45] [46]. Carcass $\mathrm{pH}$ of Arsi, Borana, Harar and HF-Cross bulls were presented in Figure 2 and Figure 3. The result of this study shows that the longissimus dorsi muscle $\mathrm{pH}$ value was decreased linearly with almost comparable rate in all breeds starting from 45 minute after slaughter up to 24 hours to achieve ultimate $\mathrm{pH}$ in case of both LDM and Semitendinosus muscle. The minimum ultimate $\mathrm{pH}$ was recorded for Harar (5.5) whereas the maximum value for Borana (5.70) in LDM. This result is

Table 9. Prediction of meat yield from live trait and primal cuts.

\begin{tabular}{|c|c|c|c|c|}
\hline & Models & $\mathbf{R}^{2}(\%)$ & MSE & P-Value \\
\hline \multirow{2}{*}{$\begin{array}{l}\text { Live Animal } \\
\quad \text { traits }\end{array}$} & $\mathrm{Y}=-0.0744+0.191(\mathrm{SBW})$ & 84.29 & 2.92 & *** \\
\hline & $\mathrm{Y}=-8.05+0.182(\mathrm{SBW})+1.51(\mathrm{BCS})$ & 89.56 & 2.43 & $* * *$ \\
\hline \multirow{6}{*}{ Primal cuts } & $\mathrm{Y}=13.03+1.82(\mathrm{ch})$ & 84.08 & 2.93 & $* * *$ \\
\hline & $\mathrm{Y}=25.86+2.45(\mathrm{rib})$ & 32.86 & 6.03 & ** \\
\hline & $\mathrm{Y}=18.28+13.41(\mathrm{plt})$ & 67.33 & 4.21 & $* * *$ \\
\hline & $\mathrm{Y}=18.35+18.02(\operatorname{tln})$ & 71.81 & 3.91 & $* * *$ \\
\hline & $Y=-5.97+3.80(\mathrm{rd})$ & 59.23 & 4.70 & $* * *$ \\
\hline & $\begin{aligned} \mathrm{Y}= & 8.62+1.04(\mathrm{ch})+0.87(\mathrm{rib})+2.56(\mathrm{plt}) \\
& +5.10(\mathrm{tln})+0.23(\mathrm{rd})\end{aligned}$ & 94.78 & 1.86 & $* * *$ \\
\hline
\end{tabular}

$\mathrm{Y}=$ meat yield $(\mathrm{kg}), \mathrm{SBW}=$ slaughter body weight, $\mathrm{BCS}=$ body condition score, $\mathrm{ch}=\mathrm{Chuck}$, plt = plate, th $=$ tender loin, $\mathrm{rd}=$ round, $\mathrm{R}^{2}=$ coefficient of determination, $\mathrm{MSE}=$ mean square error. 


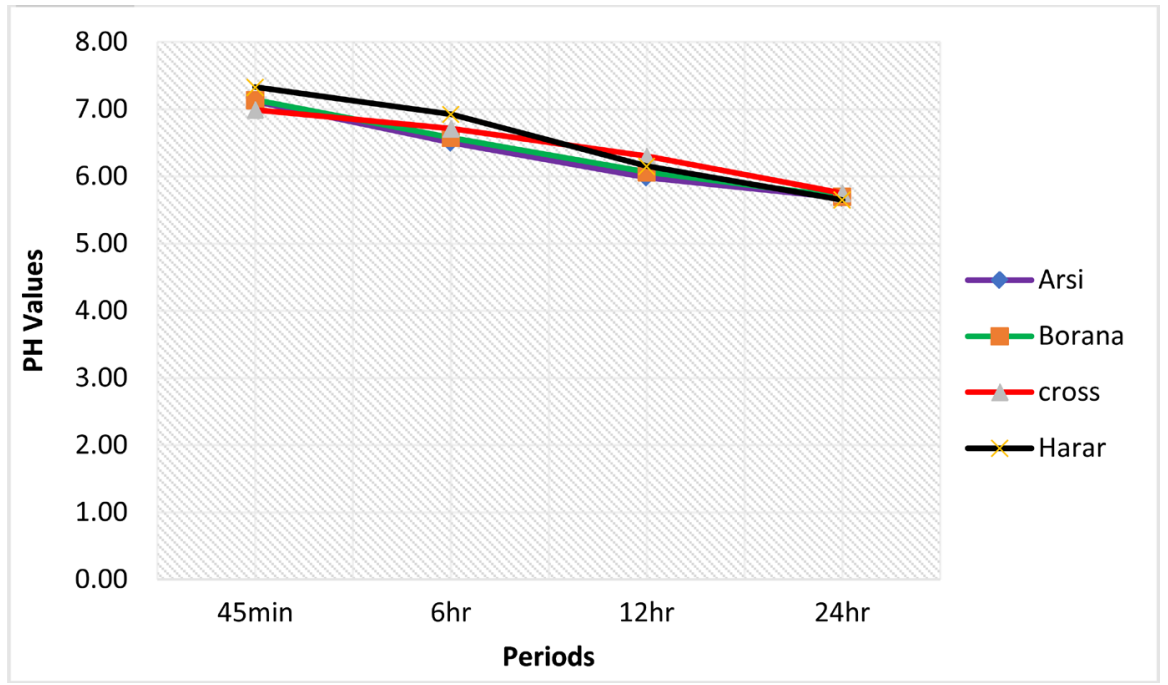

Figure 2. Longissimus dorsi muscle $\mathrm{pH}$.

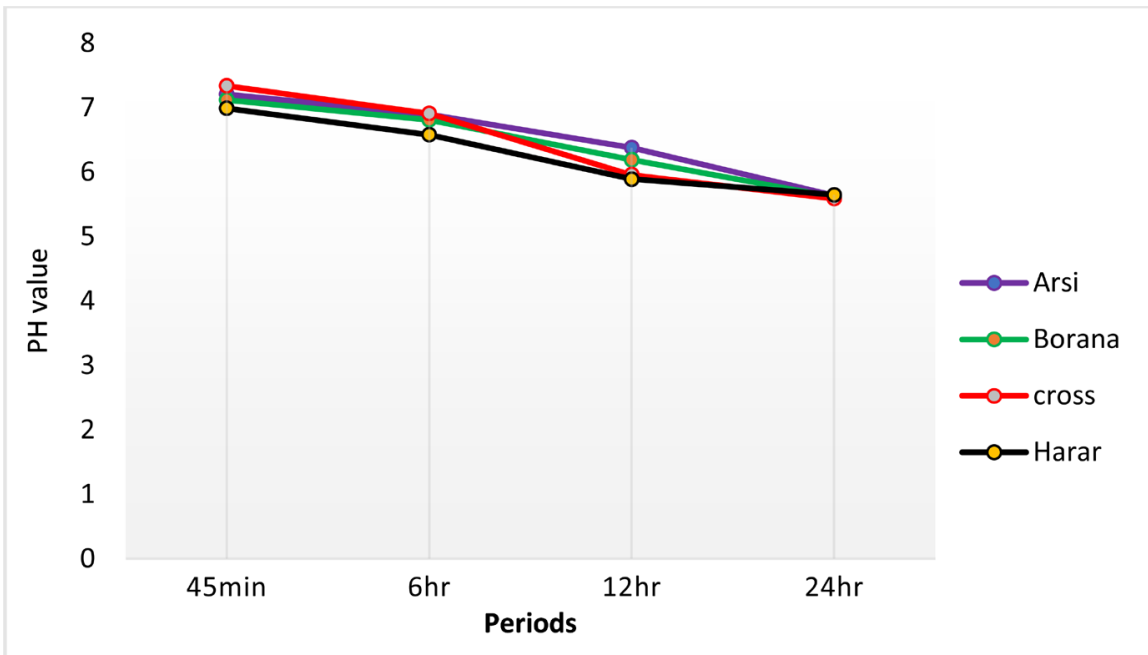

Figure 3. Semitendinosus muscle $\mathrm{pH}$.

in line with the finding of [47] for different Ethiopian indigenous cattle breeds, [16] for the same breeds with the current study. Regarding Semitendinosus muscle $\mathrm{pH}_{\mathrm{u}}$ the minimum was recorded for HF-Cross (5.59) while the maximum value for Harar (5.65). This indicates that the ultimate $\mathrm{pH}$ value in the current study in both LDM and Semitendinosus muscle were found within the normal range (5.30 to 5.70) for tropical beef [44]. Therefore, transporting Arsi, Borana, HF-Cross and Harar bulls within the average ambient temperature $\left({ }^{\circ} \mathrm{C}\right)$, relative humidity (\%), speed $(\mathrm{km} / \mathrm{hr})$, journey distance $(\mathrm{km})$, and total time spent on the truck, 25.5, 51.85, 462, and 14 hrs respectively and giving a rest for 62 hours before slaughter did not stress the animals and also did not influence meat quality.

\section{Conclusion}

From the study, it was concluded that the HF-cross and Borana bulls produced better total edible proportion. This further indicates the need to exploit dairy 
beef in addition to local cattle breeds. Concentrate supplementation improves meat yield percent of bulls from local cattle and cross breeds as compared with some previous literature on indigenous cattle in Ethiopia. Supplementing Arsi bulls with age of above five years old is not economically profitable in terms of meat yield percentage as compared with Borana, Harar and HF-Crossbred bulls. Live weight and body condition score in addition to major primal cuts could be reliable measurement in estimation of meat yield.

\section{Acknowledgements}

Many of the research findings highlighted in this article were funded in whole or part by the United States Agency for International Development (USAID) Bureau for Food Security under Agreement \# AID-OAA-L-15-00003 as part of Feed the Future Innovation Lab for Livestock Systems. Any opinions, findings, conclusions, or recommendations expressed here are those of the authors alone. Furthermore, the authors would like to acknowledge the Ministry of Science and Higher Education of Ethiopia and Oda Bultum University for the partial support of the research activities and payment of salary of the research during the study.

\section{Conflicts of Interest}

The authors declare no conflicts of interest regarding the publication of this paper.

\section{References}

[1] AACCSA (Addis Ababa Chamber of Commerce and Sectorial Association) (2015) Value Chain Study on Meat Processing Industry in Ethiopia. 1-37. http://addischamber.com/wp-content/uploads/2017/01/Value-Chain-study-on-Mea t-Processing.pdf

[2] Negassa, A., Rashid, S. and Gebremedhin, B. (2011) Livestock Production and Marketing the Ethiopia Strategy Support Program II (Essp II) Working Papers about Essp II. 26. Finfinne.

[3] Mummed, Y.Y. and Webb, E.C. (2014) Ethiopian Beef Carcass Characteristics. African Journal of Agricultural Research, 9, 3766-75.

[4] Yami, A., Tolera, A., Gizachew, L., Alemu, D., Assefa, G., Geleti, D., Mengistu, A., Bediye, S. and Woldesemayat, Y. (2012) Livestock Feed Resources in Ethiopia: Challenges, Opportunities and Need for Transformation. Ethiopia Animal Feed Industry Association, Addis Ababa, 103-128.

[5] MoA \& ILRI (Ministry of Agriculture and International Livestock Research Inistitute) (2013) Animal Production Vision and Strategy for Ethiopia.

[6] FDRE (Federal Democratic Republic of Ethiopia) (2011) Ethiopia's Climate-Resilient Green Economy. 1-200.

[7] AGP-LMD (Agricultural Growth Program-Livestock Market Development) (2013) Agricultural Growth Program-Livestock Market Development End Market Analysis for Meat/Live Animals, Leather and Leather Products, Dairy Products Value Chains.

[8] Shapiro, B.I., Gebru, G., Desta, S., Negassa, A., Nigussie, K., Aboset, G. and Mechal, H. (2015) Ethiopia Livestock Master Plan. ILRI Project Report. International Lives- 
tock Research Institute (ILRI), Nairobi.

[9] Hosaina, M.I., Rahmana, M.H., Hossaina, M.M., Akhtera, S., Hashema, M.A., Rahmanab, S.M.E. and Oh, D.-H. (2015) Effect of Age and Primal Cuts on Beef Quality of Indigenous Cattle. Journal of Meat Science and Technology, 3, 18-27.

[10] Mummed, Y.Y. and Webb, E.C. (2019) Carcass Weight, Meat Yield and Meat Cuts from Arado, Boran, Barka, Raya Cattle Breeds in Ethiopia. Journal of Agricultural Science, 11, 45. https://doi.org/10.5539/jas.v11n18p45

[11] Gebremariam, T.T. (2019) Feedlot Performance and Carcass Yield of Hararghe Highland (Bos indicus) Bulls Using Different Concentrate Feeds. Acta Scientiarum. Animal Sciences, 41, e42557. https://doi.org/10.4025/actascianimsci.v41i1.42557

[12] Dagne, T., Yusuf, Y., Yusuf, M., Urge, M., Quine, T.O. and Vipham, J.L. (2019) Effect of Age and Breeds of Cattle on Carcass and Meat Characteristics of Arsi, Boran, and Harar Cattle in Ethiopia. Open Journal of Animal Sciences, 9, 367-383. https://doi.org/10.4236/ojas.2019.93030

[13] Lemma, T., Geleta, T., Sisay, A. and Abebe, T. (2007) Effects of Four Different Basal Diets on the Carcass Composition of Finishing Borana Bulls. Journal of Cell and Animal Biology, 1, 15-18.

[14] Mekasha, Y., Urge, M., Kurtu, M.Y. and Bayissa, M. (2011) Effect of Strategic Supplementation with Different Proportion of Agro-Industrial By-Products and Grass Hay on Body Weight Change and Carcass Characteristics of Tropical Ogaden Bulls (Bos indicus) Grazing Native Pasture. African Journal of Agricultural Research, 6, 825-833.

[15] SAS (2013) Statistical Analysis Software. Users' Guide Statistics Version 9.4. SAS Institute Inc., Cary.

[16] Birhanu, A.F., Mummed, Y.Y., Kurtu, M.Y., O’Quinn, T. and Jiru, Y.T. (2019) Level of Pre-Slaughter Stress and Quality of Beef from Arsi, Boran and Harar Cattle Breeds in Ethiopia. Cogent Food \& Agriculture, 5, 1-16.

https://doi.org/10.1080/23311932.2019.1694233

[17] Bedhane, M. and Dadi, H. (2016) Growth and Slaughter Characteristics of Ethiopian Boran Breed Bull. International Journal of Livestock Research, 6, 41-50. https://doi.org/10.5455/ijlr.20150215090156

[18] Boito, B., Kuss, F., de Menezes, L.F.G., Lisbinski, E., de Paris, M. and Cullmann, J.R. (2018) Influence of Subcutaneous Fat Thickness on the Carcass Characteristics and Meat Quality of Beef Cattle. Ciência Rural, 48, e20170333. https://doi.org/10.1590/0103-8478cr20170333

[19] Park, S.J., Beak, S.H., Jung, D.J.S., Kim, S.Y., Jeong, I.H., Piao, M.Y. and Kang, H.J. (2018) Genetic, Management, and Nutritional Factors Affecting Intramuscular Fat Deposition in Beef Cattle-A Review. Asian-Australasian Journal of Animal Sciences, 31, 1043-1061. https://doi.org/10.5713/ajas.18.0310

[20] Kuswati, K., Artono, K., Susilawati, T., Rosyidi, D. and Agus, A. (2014) Carcass Characteristics of Brahman Crossbred Cattle in Indonesian Feedlot. IOSR Journal of Agriculture and Veterinary Science, 7, 19-24. https://doi.org/10.9790/2380-07431924

[21] Haile, A., Ayalew, W., Kebede, N., Dessie, T. and Tegegne, A. (2011) Breeding Strategy to Improve Ethiopian Boran Cattle for Meat and Milk Production. IPMS (Improving Productivity and Market Success) of Ethiopian Farmers Project Working Paper 26. ILRI, Nairobi.

[22] Negash, M., Lemma, T., Dadi, H., Feyera, T., Woldu, T., Alemu, T. and Shilima, B. 
(2008) Comparison of Body Weight Gain Performance and Carcass Characteristics of the Two Ethiopian Cattle Breeds under Natural Pasture Grazing Management. Livestock Research for Rural Development, 20, 117.

[23] Tolla, N., Mirkena, T. and Yimegnuhal, A. (2003) Effect of Feed Restriction on Compensatory Growth of Arsi (Bos indicus) Bulls. Animal Feed Science and Technology, 103, 29-39. https://doi.org/10.1016/S0377-8401(02)00214-6

[24] Jepsen, O. and Creek, M.J. (1976) Comparative Fattening Performance of Two Types of Cattle in Ethiopia.

[25] Diniz, F.B., Villela, S.D.J., Mourthé, M.H.F., Paulino, P.V.R., Boari, C.A., Ribeiro, J.S., Barroso, J.A., Pires, A.V. and Martins, P.G.M.A. (2016) Evaluation of Carcass Traits and Meat Characteristics of Guzerat-Crossbred Bulls. Meat Science, 112, 58-62. https://doi.org/10.1016/j.meatsci.2015.10.014

[26] Pogorzelska-Przybyłek, P., Nogalski, Z., Sobczuk-Szul, M., Purwin, C. and Kubiak, D. (2018) Carcass Characteristics and Meat Quality of Holstein-Friesian $\times$ Hereford Cattle of Different Sex Categories and Slaughter Ages. Archives Animal Breeding, 61, 253-261. https://doi.org/10.5194/aab-61-253-2018

[27] Aregawi, W.G., Philimon, T., Werkisa, C., Kidanie, D., Birhanu, M. and Workinesh, S. (2018) Effect of Improved Feeding Management on Body Weight Gain and Carcass Characteristics of Afar Bulls for Export Market. International Journal of Animal Science Research, 2, 1-5.

[28] Zhang, Y.M., Mao, Y.W., Li, K., Luo, X. and Hopkins, D.L. (2019) Effect of Carcass Chilling on the Palatability Traits and Safety of Fresh Red Meat. Comprehensive Reviews in Food Science and Food Safety, 18, 1676-1704. https://doi.org/10.1111/1541-4337.12497

[29] Knsellaa, J., Ki, J.J., Sheridana, T.A, Rowea, F., Butler, A., Delgado, A., Quispe-Ramirez, I.S. and Blairc, D.A.M. (2006) Impact of a Novel Spray-Chilling System on Surface Microflora, Water Activity and Weight Loss during Beef Carcass Chilling. The Group of Twenty (G20), 23, 483-490.

https://doi.org/10.1016/j.fm.2005.05.013

[30] Anonymous (2006) Fostering the Development of Technologies and Practices to Reduce the Energy Inputs into the Refrigeration of Food. http://www.grimsby.ac.uk/documents/defra/sectrep-meatchill.pdf

[31] Sampaio, G.S.L., Pflanzer-Júnior, S.B., Roça, R.O., Casagrande, L., Bedeschi, E.A., Padovani, C.R., Miguel, G.Z., et al. (2015) Effects of Polyethylene Film Wrap on Cooler Shrink and the Microbial Status of Beef Carcasses. Meat Science, 100, 164-170. https://doi.org/10.1016/j.meatsci.2014.10.018

[32] Nunes, I., Augusto, R., Passetti, C., Rivaroli, D.C. and Ornaghi, M.G. (2015) Carcass Composition and Cuts of Bulls and Steers Fed with Three Concentrate Levels in the Diets. Asian-Australasian Journal of Animal Sciences, 28, 1309-1316.

https://doi.org/10.5713/ajas.15.0021

[33] Perotto, D., dos Santos Abrahão, J.J., Moletta, J.L., de Paula, M.C. and Kuss, F. (2009) Physical Composition, Primary Cuts and Meat Cuts of Carcasses from Zebu and Bos taurus X Bos indicus Crossbred Cattle. Revista Brasileira de Zootecnia, 38, 1712-1718. https://doi.org/10.1590/S1516-35982009000900010

[34] Mitchell, A.D. (2007) Impact of Research with Cattle, Pigs, and Sheep on Nutritional Concepts: Body Composition and Growth. Journal of Nutrition, 137, 711-714. https://doi.org/10.1093/jn/137.3.711

[35] Parish, J.A., Rivera, J.D. and Boland, H.T. (2009) Understanding the Ruminant Animal's Digestive System. 
[36] Strydom, P.E. (2008) Do Indigenous Southern African Cattle Breeds Have the Right Genetics for Commercial Production of Quality Meat. Meat Science, 80, 86-93. https://doi.org/10.1016/j.meatsci.2008.04.017

[37] Baldassini, W.A., Chardulo, L.A.L., Silva, J.A.V., Malheiros, J.M., Dias, V.A.D., Espigolan, R., Baldi, F.S., Albuquerque, L.G., Fernandes, T.T. and Padilha, P.M. (2017) Meat Quality Traits of Nellore Bulls According to Different Degrees of Backfat Thickness: A Multivariate Approach. Animal Production Science, 57, 363-370. https://doi.org/10.1071/AN15120

[38] Aranha, A.S., Andrighetto, C., Lupatini, G.C., Mateus, G.P., Ducatti, C., Roça, R.O. and Martins, M.B. (2018) Performance, Carcass and Meat Characteristics of Two Cattle Categories Finished on Pasture during the Dry Season with Supplementation in Different Forage Allowance. Arquivo Brasileiro de Medicina Veterinaria e Zootecnia, 70, 517-524. https://doi.org/10.1590/1678-4162-9576

[39] Graham, J.F., Byron, J., Clark, A.J., Kearney, G. and Orchard, B. (2009) Effect of Postweaning Growth and Bulls Selected for Extremes in Retail Beef Yield and Intramuscular Fat on Progeny Liveweight and Carcass Traits. Animal Production Science, 49, 493-503. https://doi.org/10.1071/EA08181

[40] Silva, S.L., Tarouco, J.U., Ferraz, J.B.S., da Costa Gomes, R., Leme, P.R. and Navajas, E.A. (2012) Prediction of Retail Beef Yield, Trim Fat and Proportion of High-Valued Cuts in Nellore Cattle Using Ultrasound Live Measurements. Revista Brasileira de Zootecnia, 41, 2025-2031. https://doi.org/10.1590/S1516-35982012000900009

[41] Walter, L.-A.J., Schmitz, A.N., Nichols, W.T., Hutcheson, J.P. and Lawrence, T.E. (2018) Live Growth Performance, Carcass Grading Characteristics, and Harvest Yields of Beef Steers Supplemented Zilpaterol Hydrochloride and Offered Ad Libitum or Maintenance Energy Intake. Journal of Animal Science, 96, 1688-1703. https://doi.org/10.1093/jas/sky105

[42] Taylor, D.C., Johnson, E.R.B. and Knott, L. (1996) The Accuracy of Rump Fat Thickness and Twelfth Rib Fat Thickness in Predicting Beef Carcass Fat Content in Three Breed Types. Proceedings of the Australian Society of Animal Production, Vol. 21, 193-195.

[43] Hafid, H., Gurnadi, R.E., Priyanto, R. and Saefuddin, A. (2010) Identifications of Carcass Characteristic for Estimating the Composition of Beef Carcass. Journal of the Indonesian Tropical Animal Agriculture, 35, 22-26. https://doi.org/10.14710/jitaa.35.1.22-26

[44] Andrés-Bello, A., Barreto-Palacios, V. and García-Segovia (2013) Effect of pH on Color and Texture of Food Products. Food Engineering Review, 5, 158-170. https://doi.org/10.1007/s12393-013-9067-2

[45] MSA (Meat Standards Australia) The Effect of PH on Beef Eating Quality. No. MSA08, 17-24.

[46] Smith, G.C., Scanga, J.D., Tatum, K.E. and Belk, J.A. (2008) Post-Harvest Practices for Enhancing Beef Tenderness. http://www.Beefresearch.Org

[47] Mummed, Y.Y. (2015) Beef Carcass Quality, Yield and Causes of Condemnations in Ethiopia. PhD Dessertation, Pretoria University, Pretoria. 